Для цитирования: Young E. Rhee. Being and Relation in the Posthuman Age // Социум и власть. 2020. № 5 (85). С. 7-12. DOI: 10.22394/1996-0522-2020-5-07-12.

DOI: 10.22394/1996-0522-2020-5-07-12

\section{BEING AND RELATION IN THE POSTHUMAN AGE}

\author{
Young E. Rhee \\ $\mathrm{PhD}$ in philosophy, visiting professor, \\ Department of philosophy, Korea University, \\ president of Korea Association \\ of Philosophical Counseling and Korea Society \\ of Humanities Therapy. \\ 145 Anam-ro, Seongbuk-ku, Seoul, 02841, Korea \\ rheeye@korea.a.ckr
}

Annotation

What will be the posthuman society? As usual, there are two prospects: the pessimistic view and the optimistic view. According to pessimistic view, as technologies advance emerge new beings called

as transhuman with enhanced intelligence and physical power, and extremely long lifespan and

they will dominate humans. On the other hand, according to optimistic view, technology will benefit humans, so humans evolve via transhuman to post-

human with smart machines. There are complex

issues tangled together in the dispute between

the rival views, especially such as the natural vs.

artificial beings, human dignity and equality, and meaning of life. The aim of this article is to examine being and relation in posthuman age in the point of Nietzsche's philosophy. I examine transhuman as a typical being of posthuman age and ressentiment as its relation respectively. Nietzsche has influenced the rise of transhumanism and posthumanism, as

can be seen from direct or indirect confessions from pioneers of them, though there are debates about whether the influence is real or superficial. By paying particular attention to Nietzsche's idea of Master and Slave, ressentiment, and Overman (Übermensch), I contend that (a) in the posthuman age new classes will emerge, which correspond to Master and Slave, (b) there will be a new ressentiment of Slaves toward their Masters, and (c) Overman as a creator of new value will be required in order to solve the problem by ressentiment.

Key concepts: humanism, transhumanism, posthumanism, ressentment, F. Nietzsche.

\section{Transhuman}

Before discussing transhuman, it would be better to define humanism in order to compare transhumanism. Humanism is based on the following basic tenets: (a) Dignity: Humans have inherent dignity that distinguishes them from other organisms and artificial beings. (b) Rationality: Humans are rational, who can think, reason, and judge according to reason. (c) Autonomy: Humans are autonomous, who can make moral judgments, conduct actions with free will, and take responsibility for their actions. As will be seen soon, transhumanism keeps the tenets, but posthumanism originates from repulsion and criticism of one or more of the tenets.

The notion of transhuman is a product of transhumanism. Transhumanism is a collection of loosely connected ideas that have progressively developed over the last two centuries and its primary goal consists in human enhancement, symbolized by ' $\mathrm{H}+$ '. According to Max More, who first introduced the term 'transhumanism' in a contemporary sense, "it includes a broad metaphysical perspective on the development, direction, goal and value of life and consciousness. It goes beyond humanism by peering into the future in order to better understand our possibilities. As we move forward through time our understanding of our immense potentials will evolve; there can be no final, ultimate, correct philosophy of life" [8, p. 10] Based on the More's definition, The Transhumanist FAQ (2003) defines as follows: “(a) The intellectual and cultural movement that affirms the possibility and desirability of fundamentally improving the human condition through applied reason, especially by developing and making widely available technologies to eliminate aging and to greatly enhance human intellectual, physical, and psychological capacities. (b) The study of the ramifications, promises, and potential dangers of technologies that will enable us to overcome fundamental human limitations, and the related study of the ethical matters involved in developing and using such technologies."1

More's definition and the Transhumanist FAQ show the utopian and radical characteristic of transhumanism. Due to the characteristic, transhuman has dual nature. On one hand, it takes science and technology very seriously as a means of transforming human nature through cognitive, emotional, and physical enhancements such as health promotion, extension of lifespan, improvement of intellectual

The Transhumanist FAQ (2003). URL: https:// humanityplus.org/philosophy/transhumanist-faq. 
ability and emotional control ability. It is antihumanism in that it permits de-humanization such as cyborg or mind uploading. On the other hand, is still inherits humanism by accepting enlightenment based on reason and rationality. Hence, transhumanism is wandering and struggling between humanism and posthumanism [see $5 ; 7 ; 13$ ].

Transhuman is an intermediary transition between the human and posthuman 'whose basic capacities so radically exceed those of present humans as to be no longer unambiguously human by our current standards'. ${ }^{1}$ As such, transhuman overcomes biological conditions given to human, Homo sapiens, and the boundaries of life based on it, but still respects humanistic norms and values. Here are serious problems. Why and how can transhuman as enhanced being respect and pursue the norms and values of humans? Can all human be enhanced and be transhumans, finally evolved to posthumans? If not, the result of partial enhancement will be extreme inequality between the enhanced and the non-enhanced. How to prevent and solve the inequality? Who is responsible for it? Almost certainly, it will not be the non-enhanced. The standard response of transhumanists to the questions is that humans evolve to posthuman as ideal being and, as a result, those problems that are limited to humans, neither to transhumans nor to posthumans. But this simple answer is not sufficient, for the problems have multi-aspects ethical, social, economic, and policy one. Because posthumans are supposed to be 'no longer unambiguously human by our current standards', we have no clear idea of 'posthuman society'. In contrast, we have a relatively specific understanding of transhuman, which is a way to reach the goal, posthuman. ${ }^{2}$ For the reason, my subsequent discussions will focus mainly on transhuman.

\section{Dignity and Personhood}

Let's now examine whether the notion of dignity based on humanism can be embraced by transhumanism. Can transhumans be qualified as owners of dignity? The question is important, because maintenance or deterioration of dignity is the most fundamental problem for humans. Is it so in the case of the new being? First of all, according to humanism defined above, dignity has the following characteristics. (a) Uniqueness: Dignity is owned solely ${ }^{1}$ The Transhumanist FAQ (2003)...

${ }^{2}$ Though my usage risks simplification, it will be a good strategy when we consider that transhumanism is technology-based and posthuman is ideologybased. by humans. (b) Intrinsic property: Dignity is an intrinsic property given to humans. (c) Equality: Dignity is equally given to all humans.

The above notion of dignity has been criticized as anthropocentrism since, from the beginning, it blocks the possibility that nonhuman being can be an owner of dignity. Posthumanists, in particular, argue that uniqueness and equality should be open to non-human beings even though we acknowledge the intrinsic property. If we accept the posthuman view, the posthuman dignity will be reformed as follows: Universality, intrinsic property, and equality are owned by beings like transhuman or posthuman who have normal capacities of humans and/or extra capacities that surpass normal humans.

If transhumans satisfy the reformed notion of dignity, such beings can be thought of as dignified beings. The content of the normal and extra capacities can be defined in various ways. Above all, it is self-consciousness. If so, beings with self-consciousness can be recognized as dignified beings. Transhumans and posthumans who are supposed to be conscious of themselves, should be recognized as dignified beings. There are two expected criticisms: (a) It is meaningless to give the status of dignity to posthumans who are supposed to be totally different from humans. (b) The reformation leads to the notion devoid of any special meaning. If the notion of dignity can be applied not only to humans but also to animals such as dogs and dolphins, new Beings such as robots with artificial superintelligence, transhumans, and posthumans, then connotation of dignity will be empty. Therefore, there is no reason to apply the reformed notion already sufficiently contaminated by humanism to new humans.

To respond appropriately to the criticisms, it is necessary to justify the new notion of dignity. In doing this, we can use Singer's utilitarian theory of ethics. Singer argues persuasively that we should not distinguish humans from non-human animals and humans and animals should be treated on the same basis. He first distinguishes between human and person in order to discard the human-centered notion of dignity. The character of a person is rationality and selfconsciousness [14, p. 87]. A person is rational and self-conscious. The marks of personhood for determining whether an animal is rational and self-conscious is as follows [14, p. 78-84]. (a) A rational and self-conscious being is aware of itself as an extended body existing over an extended period of time. (b) It is a desiring and plan-making being. (c) It contains as a necessary condition for the right to life that it desires to continue living. (d) It is an autonomous being. 
According to Singer's criteria, a being with those marks can be regarded as a person, so deserves moral consideration. Singer's point is that the notion of dignity should be applied to person, not only to human. Now, chimpanzee and dolphin have personhood, so they are moral agents. However, neither fish devoid of self-consciousness nor human embryo lacking sensory power has dignity. Singer applied his notion of dignity based on personhood only to living organisms and does not consider new Beings such as transhuman or posthumans. But I think we can apply it to the new Beings and if they are rational and self-conscious, then we can admit that they are moral agents, so subject to moral considerations.

Singer's theory of personhood has been criticized, mainly because it leads radical judgments like the above view that are hard to be acceptable from humanism with respect to very sensitive ethical issues such as abortion and euthanasia. In connection with the topic of transhumanism, Sorgner is a typical critic to Singer. Sorgner thinks that Singer's suggestion is too radical and it ignores accomplishments and successes associated with the notion of human dignity in past. According to Sorgner, a greatest advantage is that "it has supported the realisation of liberal democratic systems" [17, p. 143]. Now, he suggests a hierarchy of moral statuses, according to which, (a) all beings are classified as person or non-person, (b) Only humans can be bearers of dignity, (c) humans can be non-persons or persons or bearers of dignity [17, p. 150-152]. As shown, Sorgner suggests to separate the notion of dignity from that of personhood and applies the former only to humans. According to Sorgner's hierarchy of moral statuses, posthumans can neither bear dignity nor, I guess, transhumans, though he does not express the matter explicitly.

Though Sorgner may succeed in securing a room to justify human dignity and avoid some intractable problems, there occurs another serious problem: Why people pursue to be transhuman and posthuman, who are beings devoid of dignity? Considering that transhuman and posthumans are supposed to exceed humans in various capacities and only humans can bear dignity, it is hard to understand why we should attribute the notion of dignity only to humans, beings who has less important capacities than transhumans or posthumans. Unlike posthumans, transhumans are clearly humans, enhanced humans, so, it will be natural to say that transhumans too have dignity. Bostrom, as a transhumanist, argues that dignities of human and posthuman are compatible and complementary [2, p. 213]. It is not the case that only humans bear dignity and transhuman can the bearer of dignity. Hence, the real problem is whether their dignity is the same or not as that of humans. I think transhumans can belong to the extension of the humanistic notion of dignity for two reasons: (a) Transhumans are enhanced humans, which means that they are living organisms. (b) They still respect humanistic norms and values. The traditional notion of dignity depends upon the two: life and moral agent.

\section{A New Type of Ressentiment}

Now, consider the lives of transhumans. Can transhumans live ideal lives as transhumanists contend? As discussed above, the direction of human evolution is moving from human, via transhuman, to posthuman, Transhumans are enhanced beings physically, cognitively, emotionally, and even morally. A real difference between transhumans and posthumans is that the latter is no longer classified as humans because they transcend human conditions and elements in all respects. On the other hand, the former is still humans in that they share human values despite their enhanced capacities.

We can say that a principal problem of transhuman society is a problem of social inequality. Citizens of transhuman society will be distinguished largely as the enhanced and the non-enhanced, so there will be serious inequality between them. Even if some of the inequality can be dissolved by societal policies based on good will of the enhanced, ressentiment of the non-enhanced toward the enhanced cannot be solved easily in that it is artificial and social inequality caused by technology and society, unlike primitive inequality given to humans by birth. Of course, this kind of artificial inequality may not occur if the benefits of developments in science and technology are distributed equally among citizens. However, as is well seen in human history, this kind of inequality is evitable and difficult to overcome and no such utopian ideal has ever been realized.

The second possibility of remedy comes when transhumans can be moral agents by moral enhancement (or moral bioenhancement) [see $1 ; 2 ; 3]$. However, it is very questionable, because (a) moral enhancement is harder than other kinds of enhancements such as physical and cognitive one and (b) there will be conflicts between those enhancements. Agar argues radical human enhancement, which contains his answers to the skeptical questions. First, he suggests two hypotheses 
about moral enhancement, which are in a logical accordance with the fact that it is always possible to improve the powers constitutive of practical reasoning. (a) Hypothesis 1: There is some degree of improvement of capacities constitutive of status that cognitively superior beings would recognize as creating a moral status higher than personhood. (b) Hypothesis 2: "There is no degree of improvement of these capacities that cognitively superior beings would recognize as creating a moral status higher than personhood" [1, p. 178-179]. And he recommends that we prefer the hypothesis 1 to hypothesis 2 on inductive basis. The point of his argument is that cognitive enhancement will enhance moral status. If Agar's argument is valid, then this kind of moral enhancement is less ethically problematic than other approaches such as genetic or biological one. Even if social inequality is solved, we need to keep this in mind. A real problem of the inequality still remains unsolved: Why the enhanced cares about the un-enhanced.

The various distinctions that correspond to that between the enhanced and the non-enhanced in posthuman society. Here is a typical one presented as in the following table.

\begin{tabular}{|l|l|}
\hline The enhanced & Master \\
\hline The non-enhanced & Slave \\
\hline
\end{tabular}

The distinction between master and slave comes from Nietzsche. In On the Genealogy of Morality (1887), Nietzsche explains the origin of Master morality and Slave morality. A minor but superior group and a major but inferior group are disputed, and the superior group conquered the inferior group and, as a result, the former became Masters and the latter became Slaves. The two classes have different moral system respectively. The criteria of master morality are 'good and bad' (Gut und Schlecht). The good comes from the attitude of a master that proudly affirming himself, whereas the bad is derived from the attitude of Slaves. On the other hand, the standard of Slave morality is 'good and evil' (Gut und Böse). Here, the good is revealed in the attitude of Slaves, and the evil is derived from the attitude of Master [12, § I, 11].

Slaves have deep-seated resentment, frustration, and hostility accompanied by a sense of being powerless. Nietzsche uses the notion of ressentiment in order to refer to feelings of Slaves toward their Masters [12, §।, 10, §।, 13-15, § III, 19, § III, 26-27]. However, Slaves succeeded in evangelizing the values system through a mental revolt to construct a world dominated by their morality and, as a result, everything related to their weaknesses, which were judged to be 'bad' before, were classified as 'good', and everything related to 'good' is classified as 'evil'. Slave revolt is a value evangelism driven by ressentiment.

In posthuman age, there will be a class differentiation corresponding to the Nietzschean class of Master-Slave. Transhumans and posthumans become the new masters and humans become the new slaves. According to Nietzsche, the virtue of Master is composed of affirmation stemming from superior power, while the virtue of Slaves is negativity of ressentiment, which is derived from their inferior abilities. The new slaves, who are not improved or enhanced in posthuman age, will have a new type of ressentiment to their new masters. The slave revolt was possible in the Nietzschean society of Master-Slave, but it is very unlikely to occur in posthuman age. Slave revolt reversed the value standards and, as a result, the overall level of humans has been equalized downwardly and humans gradually began to fall. From the Nietzschean point of view, new masters do not have any moral responsibility to care about the ressentiment of slaves. Since humans and posthuman are totally different, they will be given different moral status and so will have different moralities respectively, like master and slave of Nietzsche. What is important here is that in posthuman age, social equality is possible only among humans or only among posthuman, not possible between humans and transhumans or between humans and posthumans.

\section{Overman}

Nietzsche never gave an explanation of what he meant by Overman (Übermensch) and took a way of alluding to it.

When Zarathustra came into the nearest town lying on the edge of the forest, he found many people gathered in the market place, for it had been promised that a tightrope walker would perform. And Zarathustra spoke thus to the people: «I teach you the overman. Human being is something that must be overcome. What have you done to overcome him? All creatures so far have created something beyond themselves; and do you want to be the ebb of this great flood and would even rather go back to the animals than overcome humans?" [12, p. 5]

Nietzsche's unwillingness to give an exact meaning of Overman has motivated various interpretations and there are people who identify posthuman with Overman of Nietzsche. This is a mistake because even if posthuman 
is superman with good will, other conditions must be satisfied for superman to be Overman. According to Nietzsche, Overman is a being that is required as a creator of a new value system to re-establish the value evangelism brought about by the slave revolt. If posthuman is Overman, posthuman must have, above all, the ability to create new values required for posthuman age.

When Nietzsche declared that "God is dead" (Gott ist tot), what he really meant was that the metaphysical dichotomy that distinguished between God and humans, which had been taken for granted so far, was over. Nietzsche saw that such a dichotomy posed a tragedy that affirmed only the world of existence and denied the world of life. Overman in posthuman age is the creator of new value system for a new world of life in which God is not present. In this sense, Nietzsche's idea of Overman is consistent with the basic nature of posthuman age. ${ }^{1}$ When we approach Nietzsche's philosophy centering on notions of ressentiment and Overman, his philosophy functions a powerful hammer that breaks ramparts surrounding humanism, which induces us to see Nietzsche as a transhumanist or a posthumanist. Aroused by an awakening of immature humans, an unfounded taboo, and the shackles of unjust repression, Nietzsche found a road to the desirable Enlightenment Age via transhumanism.

What will be the new values for posthuman age? I guess the primary candidate is openness. Posthuman age has characteristics: hyper-connectivity, artificial super-intelligence, and super-human. Every beings and things are inter-connected and traditional dichotomies between human and non-human animal, human and machine, man and woman, and physical being and virtual being will disappear. The more we approach to posthuman age, the more there will be inter-connection among humans, transhuman, and posthuman as well as smart machines, inanimate objects, and cyberbeings. For better communication between humans and new Beings each is required to have openness to others. The dramatic reduction in difference such as personality, uniqueness, heterogeneity, and unfamiliarity will result in openness. Posthuman life will be classified into two types as follows.

(a) Comfortable but monotonous life;

(b) Creative and dynamic life.

It is expected that in posthuman age a large number of beings will live a comfortable but

\footnotetext{
${ }^{1}$ Y. Harari [6] suggests a way of understanding the nature of posthuman by naming posthuman as 'Homo Deus' who wants to be a God.
}

monotonous live, and a few will pursue creative and dynamic lives, and only a few actually live the creative and dynamic lives.

\section{Concluding remarks}

As shown so far, in order for creative and dynamic life to become a leading form of life in posthuman age, it is necessary for its citizens to develop new posthuman values. It is because of this situation that Overman is required. Socrates reminded us that life to be pursued is not a 'comfortable life' but a 'good life'. The good life in posthuman age becomes synonymous with creative life. It takes a lot of cost and effort to pursue and achieve it. This means that the gap of the rich and the poor works still as a fundamental barrier to achieving the goal. Here, we find another qualification of Overman. Overman is required to eliminate such obstacle as well as to liberate the non-enhanced from their ressentiment.

\section{Reference}

1. Agar N. (2014) Truly Human Enhancement: A Philosophical Defense of Limits. Cambridge, MA, MIT Press [in Eng].

2. Bostrom N. (2005) Bioethics, no. 19 (3), pp. 202-214 [in Eng].

3. Bostrom N., Savulescu J., eds. (2009) Human Enhancement. Oxford, Oxford University Press [in Eng].

4. Cybulska E. (2012) Philosophy Now, no. 93 (November/December) [in Eng].

5. Fukuyama F. (2002) Our Posthuman Future: Consequence of the Biotechnology Revolution. New York, Picador [in Eng].

6. Harari Y. (2017) Homo Deus: A Brief History of Tomorrow. London, Vintage [in Eng].

7. Kass L. (2002) Life, Liberty and the Defense of Dignity. San Francisco, CA, Encounter Books [in Eng].

8. More M. (2009) Entropy, no. 6, pp. 6-12 [in Eng].

9. More M. (2010) Journal of Evolution and Technology, no. 21 (1), pp. 1-4 [in Eng].

10. More M., Vita-More N., eds. 2013. The Transhumanist Reader. West Sussex, UK, WileyBlackwell [in Eng].

11. Nietzsche F. (2006) [1887]. On the Genealogy of Morality. K. C. Diethe trans. Cambridge, Cambridge University Press [in Eng].

12. Nietzsche F. (2006) [1883-85]. Thus Spoke Zarathustra. A. Caro trans. Cambridge:. Cambridge University Press [in Eng].

13. Sandel M. (2009) Justice: What's the Right Thing to Do. New York, Farrar, Straus and Giroux [in Eng]. 
14. Singer P. (1979) Practical Ethics. Cambridge, Cambridge University Press [in Eng].

15. Sorgner S. L. (2009) Journal of Evolution and Technology, no. 20 (1), pp. 29-42 [in Eng].

16. Sorgner S. L. (2010) Journal of Evolution and Technology, no. 21 (2), pp. 1-19 [in Eng].

17. Sorgner S. L. (2013) Trans-Humanities Journal, no. 6 (1), pp. 135-159 [in Eng].

18. Rhee Y. (2018) "Conscious Artificial Intelligence", in Ontology of Artificial Intelligence, Paju, Korea, Hanul Academy, pp. 80. [in Korean].

19. Rhee Y. (2020) "Cyborg", in Posthuman Comes. Paju, Acanet, pp. 59-84. [in Korean].
Для цитирования: Янг Э. Ри

(Young E. Rhee). Бытие и отношения

в постчеловеческую эпоху //

Социум и власть. 2020. № 5 (85). С. 7-12.

DOI: 10.22394/1996-0522-2020-5-07-12.

DOI: 10.22394/1996-0522-2020-5-07-12

УДК $130.2+141.2+141.3$

\section{БЫТИЕ И ОТНОШЕНИЯ В ПОСТЧЕЛОВЕЧЕСКУЮ ЭПОХУ}

Янг Э. Pu (Young E. Rhee),

доктор философии, приглашенный профессор кафедры философии Корейского университета, президент Корейской ассоциации философского консультирования и Корейского общества гуманитарной терапии. 145 Anam-ro, Seongbuk-ku, Сеул 02841, Корея E-mail: rheeye@korea.a.ckr

\section{Аннотация}

Каким будет постчеловеческое общество? Есть две перспективы: пессимистическая и оптимистическая. Согласно пессимистическому взгляду, по мере развития технологий появятся новые существа, которые можно назвать сверхчеловеческими, с повышенным интеллектом и физической мощью, чрезвычайно долгой продолжительностью жизни, и они будут доминировать над людьми. С другой стороны, согласно оптимистическому взгляду, технологии принесут пользу людям, поэтому люди эволюционируют от трансчеловека к постчеловеку с помощью умных машин.

В спор между этими конкурирующими взглядами вплетены сложные вопросы, особенно такие, как соотношение естественного и искусственного, человеческое достоинство и равенство, проблема смысла жизни. Цель данной статьи - исследовать бытие и отношения в постчеловеческую эпоху с точки зрения философии Ф. Ницше. Автор рассматривает трансчеловека как типичное существо постчеловеческой эпохи и рессентимент как его основное отношение к миру. На появление трансгуманизма и постгуманизма, как видно из прямых или косвенных признаний их представителей, оказала влияние философия Ф. Ницше, хотя ведутся споры о том, является ли это влияние глубоким или поверхностным. Обращая особое внимание на идею Ницше о Господине и Рабе, идею рессентимента и Сверхчеловека (Übermensch), автор утверждает, что (а) в постчеловеческую эпоху появятся новые общественные классы Господ и Рабов, (б) появится новый рессентимент Рабов по отношению к своим Господам, и (в) потребуется Сверхчеловек как создатель новых ценностей для решения проблем рессентимента.

Ключевые понятия:

гуманизм,

трансгуманизм,

постгуманизм,

рессентимент,

Ф. Ницше. 